Historia Slavorum Occidentis

2018, nr 2 (17)

ISSN 2084-1213

DOI: $10.15804 /$ hso180207

Ján Steinhübel (Bratislava)

\title{
Pavol Hudáček, Castrum Salis. Severné pohraničie Uhorska okolo roku 10oo, Veda, vydavatel'stvo SAV, Bratislava 2016, ss. 478
}

Kniha Pavla Hudáčka, ktorá vznikla v Historickom ústave Slovenskej akadémie vied, má predslov, zoznam skratiek, šest' kapitol, záver, anglické zhrnutie, mapovú prílohu, zoznam prameňov a literatúry a register.

Predslov (s. XI - XIII) nás oboznamuje so zámerom autora vystopovat' počiatky a nasledujúce dejiny hradu Salis a s ním aj historického regiónu Šariša, v ktorom sa tento hrad nachádzal. Zároveň upriamuje pozornost' na celé severné pohraničie Uhorska, uprostred ktorého sa Šariš rozkladal.

V 1. kapitole s názvom „Hrady z 9. - 10. storočia a Castrum Salis” (s. 1-64) je autorom riešená otázka včasnostredovekého osídlenia územia Šariša. V texte sú prezentované archeologické poznatky siahajúce od praveku až do 10. storočia v spojení s hmlistými a vel'mi nepriamymi písomnými správami, ktoré sa dotýkajú tejto doby. Následne autor venuje pozornost' kniežatu Salanovi, o ktorom písal uhorský Anonymus. Salan bol totožný s vel'komoravským kniežat'om Svätoplukom. Anonymus zmenil meno Svätopluka na Salana podla hradu Szalánkemén (dnes Stari Slankamen) na sútoku Tisy a Dunaja, blízko ktorého stál Titel, na ktorom mal Salan podla Anonyma sídlit'.

V centre pozornosti je otázka, či hrad Salis stál už v dobe vel'komoravskej. Autor sa zaujíma o sídelnú kontinuitu Slovanov po príchode Mad'arov a napokon rieši vztah hradu Salis k pol'skému Przemyślu, a to vzhl'adom na ich polohu na solnej ceste v 10. storočí. Autor sa podrobne zaoberá polohou Várhegy, južne od Solivaru, kde hrad Salis pravdepodobne stál. Všíma si nielen skromné poznatky, ktoré archeológovia priniesli o polohe Várhegy, ale aj o blízkych hradoch Obišovce (Stráža) 
a Šarišské Sokolovce (Hradová hura), o výšinnej osade vo Finticiach a o Hradisku pri Terni, ktoré sú datované do 9.-10. storočia. Hrad v Šarišských Sokolovciach má stopy požiaru (spálená hlina), mohol zhoriet' súčasne s hradom v Spišských Tomášovciach/Smižanoch pri útoku Svätopluka I. Hrady Obišovce a Šarišské Sokolovce zanikli v 10. alebo 11. storočí.

Hrad Salis vd'aka svojej polohe uprostred Prešovskej kotliny mal úlohu centra. Mohol byt' centrom pohraničného regiónu, ku ktorému patril hrad Obišovce na juhu a Šarišské Sokolovce na severe. Už v dobe vel'komoravskej sa cez toto pohraničie vozila sol' zo Sedmohradska na pol'ské územie. Hrad Salis kontroloval cestu údolím Hornádu a Torysy cez Zborovský alebo Dukliansky priesmyk (Porta Poloniae) do Malopol'ska na Krakov. Salis bol bud' už vel'komoravským hradom, alebo vznikol až v 10. storočí, ked' zobral na seba úlohu hradov Obišovce a Sokolovce, ktoré práve preto $\mathrm{v}$ tomto čase zanikli.

2. kapitola „Gesta Hungarorum, Anonymus a Uhorsko-pol'ská kronika” (s. 65$-104)$ je venovaná naračným prameňom. Hrad Salis spomína Anonymus a Uhorsko-pol'ská kronika, iní kronikári nie. Podl'a Annales sancti Crucis Boleslav po násilnej smrti krakovského biskupa Stanislava v roku 1079 utiekol z Pol'ska do Uhorska a zomrel $\mathrm{v}$ kláštore $\mathrm{v}$ uhorskom pohraničí. $\mathrm{V}$ skutočnosti však to nebol kláštor, ale hrad, autor análov zrejme zamenil castrum na claustrum. Boleslav II. mohol sídlit' na hrade (castrum) v uhorskom pohraničí, tak ako to spomína jedna verzia Annales sancti Crucis zvaná Kodex Sochaczewski (ostatné zachovania týchto análov majú claustrum.) Boleslav odišiel do hradu Salis (in castrum Salis), kde sa zabával pri pol'ovačkách, ako to spomína Uhorsko-pol'ská kronika. Pol'ské knieža Boleslav II. bol v rovnakej situácii ako Břetislav, syn českého kniežat'a a krála Vratislava II. (1085-1086-1092). Břetislav sa musel pred otcom uchýlit' do Uhorska a uhorský král' Ladislav I. ho usadil pri Bánove v komitáte Trenčín. Břetislav tam usídlil svoju dvojtisícovú družinu a sám sa zdržiaval na Ladislavovom královskom dvore.

V 3. kapitole „Boleslav Chrabrý a Castrum Salis” (s. 105-152) sa autor podrobne zaoberá úlohou hradu Salis na prelome 10. a 11. storočia a rieši vztah pol'ského kniežata Boleslava Chrabrého voči Uhorsku, Nitriansku a k samotnému hradu Salis. Podrobne nás zoznamuje s doterajšou rozsiahlou historiografiou o Boleslavovi Chrabrom, zameriava sa na jeho vztah $k$ Nitriansku a detailne analyzuje správu Uhorsko-pol'skej kroniky o hrade Salis, o uhorsko-pol'ských hraniciach, ktoré boli zároveň hranicami Nitrianska. Zaujíma ho vztah Boleslava Chrabrého a nitrianskeho kniežata Ladislava Lysého a napokon vztah Prokuja, ktorého uhorský král' Štefan I. vyhnal zo Sedmohradska a ktorý vstúpil do služieb Boleslava Chrabrého, k hradu 
Salis. Podl'a Györgya Györffyho k pol'sko-uhorskému konfliktu mohlo dôjst'len v súvislosti s vyhnaním Prokuja pred rokom $1018 \mathrm{z}$ hradu na uhorsko-pol'ských hraniciach. Autor obhajuje názor, že Boleslav Chrabrý obsadil Nitriansko v roku 1003. Saský kronikár Thietmar spomína Prokujov hrad ako quandam urbem. Nič bližšie teda o ňom nevedel, tak ako ani o ostatných uhorských hradoch. Autor sa priklonil k názoru, že týmto hradom nebol Salis, ale Bratislava.

V 4. kapitole „Castrum Salis a Anonymus” (s. 153-208) sa autor podrobne a kriticky zaoberá Anonymovými správami o hradoch horného Potisia: Užhorod (Uh), Boržava, Zemplín, Boršod/Borsod, Tarcal, Serenč/Szerencs a Sárospatak (Patak, Ketelpataka). Zaujíma ho aj kláštor Százd a župan (comes) Peter, ktorých spomína listina asi z roku 1067, a jágerské biskupstvo, ktorému celé toto územie cirkevne podliehalo, tiež Krásna nad Hornádom a vztah hradov Salis a Boršod/Borsod. Autor dospel k názoru, že „hrad Zemplín sa nachádzal na pravej strane Bodrogu, preto už nepatril do Užského komitátu. Bol pravdepodobne súčastou susedného komitátu Boršod” a s ním do Boršodského komitátu patrilo aj „územie na lavej strane Bodrogu popri Zemplínskych vrchoch”. Ďalej tvrdí, že „král'ovský dvorec a kaplnka v Pataku/ Sárospataku”, ktoré ležali na tomto území, boli král'ovským majetkom, ktorý „nachádzal sa na území Boršodského a neskôr Zemplínskeho komitátu”. Anonymus pri písaní svojho diela mohol mat'v rukách spomínanú donačnú listinu pre kláštor Százd, ktorú župan Peter vydal okolo roku 1067, a v ktorej sa spomínajú najstaršie abovské majetky, ktorých čast' župan Peter daroval kláštoru. Král'ovské majetky dokladá aj listina majetkov a práv jágerského biskupstva z roku 1261/1271, ktoré získalo od Štefana I. a Ladislava I. Pôvodnú listinu mohol vydat Štefan I. v roku 1009. V listine z roku 1261 sa určite upravili názvy komitátov podl'a aktuálnej situácie. Hrad Salis strážil severný okraj komitátu Boršod, ktorému autor venuje značnú pozornost'. Spojil informácie Uhorsko-pol'skej kroniky a uhorského Anonyma a dostal územný rozsah a hranice vel'kého Boršodského komitátu.

5. kapitola „Uhorské pohraničie, obchod, sol' a cesty v 11.-12. storoči” (s. 209-316) nás oboznamuje s král'ovskými pohraničnými lesmi v Karpatoch, s krajinskými bránami, zásekmi a s pohraničnými hradmi. Zaoberá sa cestami, trhmi a obchodom, predovšetkým obchodom so sol'ou. Autor prichádza k významnému záveru, že hrad Salis v 11.-13. storočí nechránil sol'né žriedla, ktoré vyvierali v jeho okolí, ale bol jediným král'ovským sol'ným skladom $\mathrm{v}$ uhorsko-pol'sko-ruskom pohraničí, na ktorom sa skladovala sedmohradská sol'. Salis, ktorý mal výhodnú polohu na sútoku Torysy a Sekčova, kontroloval cestu cez Karpaty. Severne od hradu Salis sa cesta rozdvojovala. Jedna viedla do krajinskej brány medzi Pečovskou Novou Vsou 
a Červenicou a druhá do krajinskej brány medzi Demjatou a Raslavicami. Vznikli tam král'ovské mýtnice, usadili sa strážcovia hraníc a v podhradiach komitátnych hradov, pri král'ovských dvorcoch a v dôležitých král'ovských dedinách vznikli král'ovské trhy (fora). Je vel'mi pravdepodobné, že hlavná cesta do Pol'ska a na Rus, ktorá viedla údolím Hornádu a Torysy, šla práve cez hrad Salis.

V Uhorsku bolo niekol'ko sol'ných hradov. Sol', ktorá sa plavila zo Sedmohradska po riekach Maroš a Tisa, sa skladovala na hradoch Szalánkemén (Stari Slankamen), Titel a pravdepodobne aj Alpár. Obchod so sol'ou upravovala Zlatá bula z roku 1222. Sol' sa nemala skladovat vo vnútrozemí král'ovstva, s výnimkou hradov Szalancs a Segedín/Szeged, ale len v pohraničí. Listina pre domošský kláštor z roku 1138 spomína dopravu soli ad forum Sumbuth. Tento Sumbuth môže byt' Ostrihom, spomínaný v anonymnej legende o utrpení svätého Vojtecha ako Sobottin, teda sobotný trh. Hlavné sol'né sklady Arpádovcov boli na hradoch Szalancs, Segedín/Szeged (a možno aj v Szolnoku) a na sedmohradských hradoch Torda, Doboka a Dés. Sol' sa skladovala aj na pohraničných hradoch Bratislava, Mošon/Moson a Šopron/Sopron. Ked'že hrad Salis tiež ležal v pohraničí a získal svoje meno podl'a soli, je vel'mi pravdepodobne, že sedmohradská sol' sa vyvážala do Pol'ska a na Rus práve cez tento hrad. Solný sklad bol aj na Castrum Ferreum (Kismárton, Eisenstadt) v Šopronskom komitáte. Ďalší Castrum Ferreum (Vasvár, Eisenburg, Železný hrad) bol centrom pohraničného Železnohradského komitátu. Oba pohraničné železné hrady nemali nič s tažbou železnej rudy, ale boli skladmi železa v uhorsko-nemeckom pohraničí. Pohraničným skladom bol aj Castrum Salis, ktorý má podobné meno ako Castrum Ferreum, skladovali v ňom sedmohradskú sol'. Dial'ková cesta, ktorá z Uhorska smerovala do Pol'ska a na Rus, na ktorú dohliadal hrad Salis, sa v 13. storočí spomína ako magna via a via regis.

V 6. kapitole s názvom „Severné pohraničie Uhorska a Castrum Salis” (s. 317-380) sa autor sústred'uje na samotný Šariš, vztah hradov Salis a Šariš, na krajinské brány, záseky a strážcov v Šariši. Autor hl'adá územie hradu Salis, pričom vychádza z údajov o král'ovskom majetku Sóvár/Solivar z 13. storočia. Ladislav IV. daroval Jurajovi, synovi Šimona, Sóvár/Solivar a Sópatak/Sol', ktoré ležali na l'avom brehu Sekčova, spolu s vel'kým lesom, ktorý siahal až k Topli. Sekčov bol zrejme západnou hranicou a Topla východnou hranicou král'ovského majetku, spomínaného v roku 1261 ako districtus predii nostri de Souuar. Na severe ho ohraničoval potok Redník (dnes Medziansky potok) a potoky Ladianka a Šebastovka, na západe rieky Sekčov a Torysa. Južná hranica začínala na sútoku Torysy a Bohdanovského potoka a tiahla sa cez Slanské vrchy medzi dedinami Čižatice a Kecerovce k Topli. Autor prijíma 
názor Branislava Varsika, že hrad Salis zanikol pravdepodobne v roku 1242 v dôsledku tatárskeho vpádu. Dediny, ktoré patrili k hradu Salis, získal hrad Solivar/Sóvár.

V závere (s. 381-392) autor zdôrazňuje, že hrad Salis, ktorý bol významným skladom soli, nikdy nebol centrom vel'kého územia, ako nimi boli komitátne hrady. Salis sa skôr podobal hradom Locsmánd alebo Kapuvár v západnom pohraničí Uhorska, prípadne považským hradom Šintava, Hlohovec, Bana alebo Beckov. Výstižné je porovnanie so Železným hradom (Castrum Ferreum) v západnom pohraničí Uhorska, ktorý bol tiež významným skladom, nie však soli ale uhorského železa. Knihu doplňa anglické zhrnutie (s. 393-405), mapová príloha (s. 406-408), rozsiahly a vyčerpávajúci zoznam prameňov a literatúry (s. 409-460) a register (s. 461-477).

Monografia Pavla Hudáčka poskytuje vynikajúci pohlad na málo spomínaný hrad Salis a na celé severné uhorské pohraničie vo včasnom stredoveku, kde tento hrad hral významnú úlohu predovšetkým ako sklad uhorskej soli, určenej na vývoz. Dôkladná argumentácia a podrobný výklad svedčí nielen o autorovej širokej znalosti prameňov a literatúry, ale aj o jeho schopnosti riešit zložité otázky podrobne a detailne ako na mikroregionálnej a úzko špecifickej úrovni, tak aj v širokých (celouhorských a stredoeurópskych) súvislostiach a výstižných analógiách. Autorove podrobné analýzy a výsledná syntéza s jasne formulovanými výsledkami a novými poznatkami rozširuje poznanie stredovekých slovenských a uhorských dejín s presahom do širšieho stredoeurópskeho priestoru. Kniha Pavla Hudáčka osloví historikov rôzneho zamerania i širšiu vzdelanú a kultúrnu verejnost' na Slovensku a v blízkom i vzdialenejšom zahraničí.

mgr. Ján Steinhübel, CSc.

P. O. Box 198

Historický ústav SAV

Klemensova 19

81499 Bratislava

jan.steinhubel@savba.sk 